\title{
LIMD1 wt Allele
}

National Cancer Institute

\section{Source}

National Cancer Institute. LIMD1 wt Allele. NCI Thesaurus. Code C51265.

Human LIMD1 wild-type allele is located in the vicinity of 3p21.3 and is approximately 85 $\mathrm{kb}$ in length. This allele, which encodes LIM domain-containing protein 1, plays a role in intracellular signaling, transcriptional regulation, cellular growth and cellular differentiation during development. The LIMD1 gene may have a role in tumor suppression. 